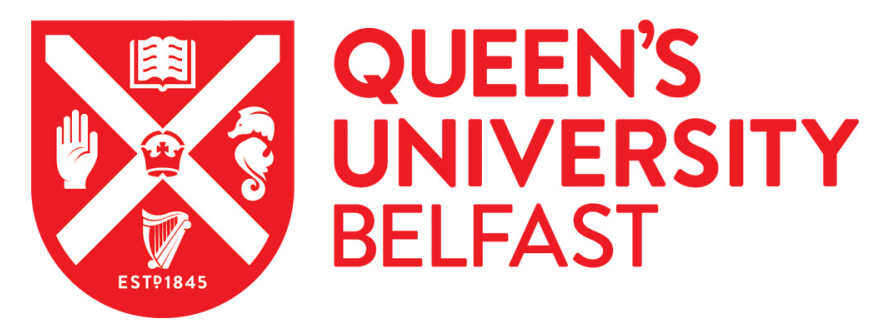

\title{
Multiple Methods in Action: Association Football, the Military and Invisible Nationalism
}

Penn, R. (2018). Multiple Methods in Action: Association Football, the Military and Invisible Nationalism. SAGE Research Methods: Cases, 1-20. https://doi.org/10.4135/9781526438706

\author{
Published in: \\ SAGE Research Methods: Cases
}

Document Version:

Publisher's PDF, also known as Version of record

Queen's University Belfast - Research Portal:

Link to publication record in Queen's University Belfast Research Portal

\section{Publisher rights}

(C) 2018 Sage Publications.

This work is made available online in accordance with the publisher's policies. Please refer to any applicable terms of use of the publisher.

\section{General rights}

Copyright for the publications made accessible via the Queen's University Belfast Research Portal is retained by the author(s) and / or other copyright owners and it is a condition of accessing these publications that users recognise and abide by the legal requirements associated with these rights.

Take down policy

The Research Portal is Queen's institutional repository that provides access to Queen's research output. Every effort has been made to ensure that content in the Research Portal does not infringe any person's rights, or applicable UK laws. If you discover content in the Research Portal that you believe breaches copyright or violates any law, please contact openaccess@qub.ac.uk. 


\section{Multiple Methods in Action: Association}

\section{Football, the Military and Invisible}

\section{Nationalism}

Roger Penn

Queen's University Belfast, UK

Discipline

Sociology [D1]

Sub-discipline

Sociology of Sport and Leisure [SD-Soc-17]

Academic Level

Postgraduate

\section{Contributor Biography}

Roger Penn is currently p professor of s Sociology, Queen's University Belfast, and is also

V*isiting Pprofessor, International Center of Research in International Management (ICRIM),

Università Cattolica del Sacro Cuore, Milano. Previously, he was Pprofessor of Economic

Sociology and Statistics, Lancaster University, and $\underline{P} ¥ i$ isiting $\underline{p}$ professor at the University of 
Bologna; the University of California, Los Angeles (UCLA); and the University of California, Berkeley. He has authored 14 books, including Children of International Migrants in Europe (Palgrave Macmillan, 2009), Social Statistics: 4 Volume Edited Series (SAGE, 2010), and The Statistical Analysis of Continuous Data: 4 Volume Edited Series (SAGE, 2013), and 150 refereed journal articles in economic sociology, quantitative methods, and the sociology of football.

\title{
Published Articles
}

Penn, R., \& Berridge, D. (2016). Football and the military in contemporary Britain: An exploration of invisible nationalism. Armed Forces \& Society. Advance online publication. doi:10.1177/0095327X16682784

Commented [CE1]: AQ1 New Deatils provided in author query document

\begin{abstract}
This case study takes the reader through the multiple methods I deployed in the research into “Association Football, the Military and Invisible Nationalism:”. These methods included observation, interviews, case studies, focus groups, literature reviews, discourse analysis, historical research, and the collection and deployment of visual data into the argument. This case study explores how these various elements coalesced into the final interpretation incorporated in the published article. It also details the process involved in transforming the initial first draft of the paper into the final published version and outlines both the time it took and its complexity. The case emphasizes the synthesis of different conceptual schemes into a novel hermeneutic approach.
\end{abstract}

\section{Learning Outcomes}

By the end of this case, students should be able to: 
- Grasp how to integrate a multiplicity of different research methods in the analysis of a set of sociological research questions

- Explain how visual data can be incorporated into both research design and the presentation of an empirical sociological argument

- Understand the various stages that a research paper must go through from its first draft to its final publication in an academic journal

- Comprehend how to respond to multiple referees' reports

- Explain the iterative nature of the creative processes involved in the production of a journal article in sociology

- Understand how multiple methods can be fused into a novel hermeneutic approach

\section{Case Study}

\section{Multiple Methods in Action: Association Football, the Military and Invisible Nationalism}

This case study is designed to explain the process whereby "Association Football, the Military and Invisible Nationalism" was created and subsequently published in the American journal, Armed Forces and Society (Penn, 2016). The research began with an observation and a puzzle. While watching the 2014 Football Association (FA) Cup Final on television, as the players of both teams were standing in the tunnel ready to walk out onto the Wembley turf, I was surprised to see alongside the players a naval rating holding the new FA Challenge Cup trophy. He was then shown walking onto the field of play and placing the trophy on a plinth beside the pitch. 
This evoked no comment at all from the television commentary team covering the match for $B T$ Sport. I wondered what this signified.

The next day, I consulted the main U.K. Sunday newspapers and discovered that they had not mentioned this episode either. This led me through a convoluted Internet search to try and uncover the back story to these events about which both the visual and print media had been silent. In the end, I discovered part of the answer on the Ministry of Defence's website. The sailor___ Liam O'Grady___ had won the Military Cross in Afghanistan in 2012. He had been a Royal Navy medical assistant on secondment to the British Army and had displayed conspicuous gallantry during a grenade attack.

As this initial exploratory phase of the research progressed, I was reminded of an event I witnessed personally at an earlier play-off match between Rochdale and Stockport County at Wembley in 2008. At that game, prior to the players entering the arena, a parade of members from different branches of the armed services as well as various emergency services in their respective uniforms walked around the perimeter of the pitch to thunderous applause from the crowd of 35,000 . I was sure that I had photographed that event and pleasingly the picture was located in my folder of photographs taken at the game. These phenomena indicated that the military were present at major football events in England and their presence generally merited no comment. They were "invisible.". My ensuing research involved an analysis of what this meant in a wider context.

Courses on social research methods and accompanying textbooks have proliferated in the last 20 years in Britain and elsewhere (see, for example, Babbie, 2010; Bryman, 2012; Gray, 2014). None, in my experience, really explain the research process as it actually occurs. A 
central purpose of this case study is to reveal how research proceeds in practice from initial ideas to a published journal article. I certainly did not have a "theory" of what was under scrutiny beyond my everyday theories of social life that we need as meaningful social actors (see Schutz, 1962). Everyone perforce uses these but what makes for social science is the interplay of conceptual thinking and empirical evidence. However, even that precept does not capture the way the research was actually pursued.

I approached the topic using a wide range of research tools. These included an extensive review of appropriate literature, analysis of visual materials on television and DVD, the collection of visual data, face-to-face interviews, case studies, and the use of focus groups as well as extensive historical research. These will be presented successively for ease of understanding, but in practice, they often occurred simultaneously and mutually interacted.

The research problem lay at the interface of the sociology of sport and the sociology of the military. In Britain, these are generally seen as tangential to the core concerns of sociology. The reasons for this are complex and lie deep in history of the discipline over the last 50 years and in the underlying implicit hierarchy of knowledge that is embedded within its trajectory. Quite how football, which is central to British culture and British discourse (see Penn, 2016) and which has produced by far the largest ever television audiences in the country, is seen as a trivial subject by most sociologists tells us more about intellectual snobbery within the discipline than about the sociological significance of football support.

The military are even less popular among the dominant tropes of British sociology. Very few university degrees feature courses on the sociology of the military, despite Britain's perennial wars and its massive defense industries. 


\section{Literature Review}

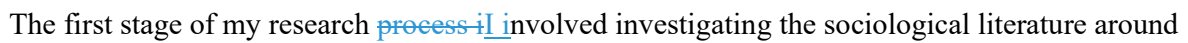
the topic. I was assisted in this by the Subject Librarians at Queen's University Belfast (Norma Menabney) and Lancaster University (Andy Holgate). The literature unearthed was overwhelmingly American. It shared two dominant parameters. It did not deal with soccer but rather focused on the major U.S. sports___ football, hockey, baseball, and basketball. It was also, as far as I could ascertain, overwhelmingly hostile to the military, particularly to its involvement in the sporting arena. As a Weberian sociologist committed to value neutrality (see Weber, 1949) _ - it is easy to condemn, far harder to understand in my experience__ _ I wanted to avoid overt partisanship. It quickly became apparent to me that the specialist sociological journal Armed Forces \& Society was the main forum for articles on sport and the military, so I decided early on to target that journal.

I also wanted to incorporate visual evidence (see Emmison, Smith, \& Mayall, 2012; Pink, 2012; Rose, 2007; Van Leeuwen \& Jewitt, 2001) to support my empirical claims wherever possible, as I had been developing an increasing expertise in this field, teaching courses on visual research methods, and publishing both articles and videos that included visual materials (Penn, 2006, 2015). I approached the editor of Armed Forces \& Society (Patricia Shields) and asked her whether the journal would accept an article on soccer and whether it would countenance photographs as part of the text. She replied positively on both counts but pointed out that the journal had not published photographs before and that it would be better not to include too many.

The journal was chosen for two main reasons. Most recent literature on the topic researched had been published in this particular specialist sociology journal. The journal was 
also based in the United States which traditionally has been a difficult area for British sociologists to publish in.

\section{Probing Invisible Nationalism and the Military: Focus Groups, Visual Analysis, and Interviews}

This part of my research involved an examination of the 2015 FA Cup Final between Aston Villa and Arsenal in order to probe these phenomena in greater detail. The game was televised live on $B B C 1$ and BT Sport. I recorded both programmes and scrutinized them in detail over subsequent days. Before the match, the Band of the Brigade of Gurkhas played music. This was not mentioned at all on either BBC1 or BT Sport, both of which televised the game live. In fact, the choice of the Gurkhas (who originate from Nepal) was deeply symbolic of their historic imperial links as 2015 represented the 200th anniversary of their service within the British Army.

The FA Cup was brought onto the pitch and placed on a plinth by a Gurkha soldier in full uniform. This was neither shown on $B B C$ nor mentioned by their commentary team. $B T$, on the contrary, showed the episode but did not comment upon it. The soldier was Sergeant Dipprasad Pun who had received the Conspicuous Gallantry Cross for his actions in Afghanistan in 2010. Subsequently, the hymn "Abide with Me" was sung by a choir of 64 fans, each of whom represented one of the 64 clubs that had featured in the third round of that year's competition. The $B B C$ commentator called it "one of those great traditions of the Cup Final," despite its novel character. Clearly, there were very similar tropes to the preceding FA Cup Final evident once more. 
I examined these phenomena systematically through the use of four mini focus groups of five students who at the time were taking part in a course on visual methods at Queen's University. These focus groups were recruited voluntarily and were based upon informed consent. I did not record the focus groups but I took notes at the time they took place. I acted as moderator for each focus group (see Kreuger \& Casey, 2014; Morgan \& Kreuger, 1997). The video presentations concentrated on the pre-match preamble on both channels and I asked students to discuss what they had seen. By no means had all of them watched the match previously and some expressed a lack of interest in football itself. Nonetheless, they all entered into the spirit of the focus groups. The technique used involved video elicitation whereby watching a video is used to prompt reactions to visual phenomena (see Haw \& Hadfield, 2011; Lapenta, 2011). Subsequently, I posted the first draft of the article onto their course Intranet site for them to read and comment upon.

None of the focus groups mentioned the presence of the Band of the Brigade of Gurkhas nor, perhaps more surprisingly, the presence of Sergeant Pun on the pitch. When I raised this after the completion of the focus groups, it became evident that the students' perceptions and interpretations were strongly influenced by the television commentaries themselves. This led me to probe the discursive parameters of the television commentaries as a set of accomplished journalistic practices. Such an approach combined elements of classic discourse analysis (see Gee, 1999; Johnstone, 2008) with its emphasis on what is rendered visible ("present") and what is simultaneously rendered invisible (“absent”), with elements of ethnomethodology (see Garfinkel, 1967, 2002; Heritage, 1984) with its focus on human agency in the accomplishment and reproduction of everyday social practices. 
I was helped in this task by James Phillips at BBC Radio Cumbria. He arranged for me to spend several afternoons with him as he undertook live radio commentaries of Carlisle United matches. From my observations, I noticed the intense pressure on commentators to describe and assess live matches. He was surrounded by a laptop, a high-end mobile phone, and an iPad, as well as his sound equipment required for the broadcast itself. In addition, a pundit (an exprofessional footballer) sat next to him. His commentary lasted from 1:00 p.m. to around 6:00 p.m. more or less constantly. To describe the events of the match, he would rely on discursive templates central to football commentaries as well as routine "football talk" (see Penn, 2016).

In this context, much of what was happening fell outside his gaze. For immediate information on Carlisle's opponents and events like a military guard of honour as the referee and players entered the pitch, he would rely almost always on press briefings that were shared between print and radio journalists (and no doubt television commentators if present). During a subsequent interview, James told me that he was convinced that the lack of comment by the television commentators on the events outlined earlier were mainly because they would have been framed as extraneous and partly because neither Wembley not the FA had provided any information on these phenomena in their pre-match briefings. This interpretation is supported by the complete absence of any comment on these events in any of the print media's reports on the games the next day. The lack of any mention on the FA's own website reinforced this assessment

The summer of 2014 witnessed an explosion of public events commemorating the century of the outbreak of World War I. As part of my widening research into the relationship of football and the military, I recorded a series of live football matches on television in November 2014 around the time of Armistice Day on November 11. I also recorded Rugby Union 
internationals in Britain during this time and analyzed the recordings. I noticed an interesting contrast. The tributes at football games focused overwhelmingly on the centennial anniversary of the outbreak of the Great War. The commemorative elements at the Rugby Union internationals were much more general and explicit references were made to the continuity of "sacrifices" made in both World Wars and in more recent conflicts in Iraq and Afghanistan. Such contrasts led me to consider examining the specificities of the relationship between football itself and the military using the comparative method. Thus, I decided that I could develop further research around this comparison.

\section{Investigating British Nationalism: Observation and}

\section{Historical Research}

The research so far had revealed that the involvement and incorporation of the military into sporting events in England had new elements but it also fitted into much wider motifs that involved the interconnections of the military, the monarchy, and the Established Church of England. The FA Cup Final has embodied these tropes for more than a century. These have been progressively sedimented into the very bedrock of the rituals surrounding the FA Cup Final itself. The monarch (or a close member of his or her family) has attended Cup finals since 1914. This is part of the wider public visibility of the monarchy in the modern age.

Football is England's most popular game and the FA Cup Final has been the centerpiece of the season both for supporters and players until very recently. It remains an important national ritual. The hymn "Abide with Me" has been sung since 1927 and was introduced into the repertoire and choreography of successive Cup Finals as part of the general commemoration of 
the military sacrifices during and since World War I. Indeed, it was part of a wider set of traditions created during the 1920 s.

The notion of the "invention of tradition" associated with the seminal work of Eric Hobsbawn and Terence Ranger (1983) provided an invaluable heuristic device that emphasized the historical, contingent nature of contemporary nationalist rituals. Modern nationalism itself is an invented tradition that needs to be constantly reiterated and reformulated. The military have long featured in the Cup Final rituals with bands from various branches of the armed forces entertaining the crowd both before kick-offs and during half-time intervals. The monarch is head of state, head of the military, and head of the Church of England. Prince William — - a keen football player and supporter__ _ is the current President of the FA.

This part of my research was initially based upon observation (see Smart, Peggs, \& Burridge, 2013) and historical analysis (see Hall \& Bryant, 2005). I had watched every Cup Final since 1958 either at Wembley or more frequently live on television. I triangulated my memories by viewing recordings of recent Cup finals and DVDs of historic Cup finals (see The F.A. Cup Finals, 2011). Recent developments have built upon longstanding historical tropes on nationalism but have also involved a step change in the involvement of the military in football.

\section{Local Case Studies of Football and the Military}

I probed the research topic further with two case studies of professional football clubs in the North West of England: Bolton Wanderers and Carlisle United. This was undertaken to explore how the phenomena uncovered at a national level were evident at a local level. The North West region is the historic center of professional football in England and had been the location of 
several previous research projects on football at Lancaster University (see Penn, 2005, 2006a). In both cases, I located key informants employed by the two clubs. Such informants have been long recognized as crucial for ethnographic and related styles of empirical research (Whyte, 1943).

In the case of Bolton Wanderers, my contact was the club chaplain, Phil Mason. I contacted him initially by email and he responded very quickly and proved immensely helpful on several occasions. Subsequently, he consented to an interview (see Arksey \& Knight, 1999) and provided me with a wide range of materials, including photographs. All of this was invaluable as I had not or could not attend any of the events in 2014 and 2015.

It was a similar story at Carlisle. James Phillips from BBC Radio Cumbria put me in contact with Andy Hall, Press Officer at Carlisle United. He also consented to an interview and provided an extensive set of photographs depicting various aspects of the club's links to the Duke of Lancaster's Regiment based in the city.

Both of my key informants were very helpful to the research. This was partly because in my initial approaches, I outlined my research interests succinctly and clearly in lay persons' language. Both generously provided permission for the use of the images from the two clubs used in the article. The first case study built upon earlier visual research at Bolton Wanderers' stadium that was incorporated in "Cathedrals of Sport" (Penn, 2015).

\section{Theoretical Approaches}

My research involved the application of a range of conceptual approaches within which the empirical materials were situated and interpreted. A powerful underlying theoretical framework involved the application of the social scientific model developed originally by the French 
"Annales" school of structuralist history. My intellectual background has always involved the simultaneous combination of historical and sociological approaches to the study of social change (see Penn, 1985, 2006b, 2013). Much contemporary sociology is devoid of any recognition or understanding of historical patterns which is a systemic weakness.

The Annales approach (see Braudel, 1979; Burke, 1972; Duby, 1973; Le Roy Ladurie, 1978) involves three core hermeneutic principles: structures, conjunctures, and events. The latter refer to the empirical materials traditionally used by historians. An example would be the Hillsborough disaster in 1989. Conjunctures embody wider cultural, political, economic, and social configurations and parameters within which such events are located. Structures refer to much longer periods (the longue durée) that persist over centuries and within which changing conjunctural patterns and the flux of events are situated. In a polemical critique of the presuppositions of classical Marxism, the "Annales School” argued that these structures were not primarily economic but were, far more often, demographic and cultural in nature.

Given this conceptual framework, my research involved widening the analysis both in terms of the present conjuncture and of the longue durée of modern Britain since the 17th century. The latter involved my undertaking extensive historical research of secondary literature about long-term popular attitudes toward the military in Britain since the 17th century when hostility toward a "standing army" after the English Civil War and the military dictatorship of Cromwell was strongly cemented into popular consciousness. This phase of the research process also involved me in examining the contrasting roles of the British Army and the Royal Navy during the century of British global dominance after the defeat of Napoleon at Waterloo. The historical research of secondary works revealed that by the 1960 s, military values and, by 
extension, the military itself had become widely unpopular in Britain. The present conjuncture was dated by me therefore as starting from the Falklands War in 1982.

Since the Afghan and Iraq Wars fought during the Blair years (1997-2007), the British $\frac{9}{5}$ Government has instigated a much wider set of institutions and practices designed to promote closer links between the citizenry and the armed forces. These have included Armed Forces Day and burgeoning links between the military and the educational system. Uncovering these developments involved extensive research based mainly on the Internet but it also involved attending events on Armed Forces Day in 2014 and 2015 as well as recording a BBC Radio 4

Formatted: Font: Italic discussion on June 28, 2015 during the programme "Sunday" about the growing links between the military and education in Britain. Subsequently, I obtained from the Quakers a DVD titled The Unseen March (https://www.quaker.org.uk/news-and-events/news/unseenmarch), outlining their critique of these emergent conjunctural developments.

I examined the contrast between the responses of crowds to the military and related nationalist expressions like the National Anthem through personal memories of FA Cup Finals attended or watched on television as well though watching historical recordings of Cup Finals on DVD (see Liverpool F.A. Cup Finals, 2005; Manchester United F.A. Cup Finals, 2005; 1970s F.A. Cup Finals, 2005; 1980s F.A. Cup Finals, 2005). The Annales model underpinned much of the argument that I developed for the subsequent research article.

My research also instantiated the fundamental precept of value neutrality derived from Weber (1949) and which forms a central tenet of the Weberian tradition of sociology. In the published article, I recognized that the phenomena under scrutiny were contested in certain contexts, presenting examples from Celtic and James MacLean's longstanding refusal to wear a 
poppy on his club shirt to commemorate Remembrance Day. However, the central focus of my research was neither to condemn nor to applaud these developments but rather to explore them and to situate them in their appropriate historical context.

\section{Invisible Nationalism: Focus Groups, Discourse Analysis, and Interpretive Methods}

The notion of invisible nationalism was the most difficult part of the argument to construct. I initially based the argument on the absence of comment by television commentators about the role of the military in their broadcasts of the 2014 and 2015 FA Cup Finals. Of course, I had noticed these phenomena and my puzzlement led to the subsequent empirical research. Initially, I chatted with colleagues who had watched the televised game and none of them had noticed the events observed. Subsequently, I organized focus groups to explore this invisibility more formally.

This posed a dilemma. I did not want to either prompt or lead my respondents, so I asked the focus groups very general and sometimes even quite vague questions. These invited participants in the mini focus groups to answer open-ended questions such as the following:

"What was happening in the video you just saw?"

"What do you remember about the video that you just watched?"

While the group discussions took place, I made notes.

As moderator, I rarely had to intervene in these group discussions. Only after finishing the formal focus group did questions about the phenomena of interest arise. Because the 
respondents had not noticed them, I decided to widen the scope of the research to encompass football commentaries. This formed part of parallel research into the discursive parameters of "football talk" which has also been published recently (Penn, 2016). I was greatly assisted in this by James Phillips at the $B B C$ who allowed me to observe several of his live commentaries.

In the end, the central claim I made in the published article was that these phenomena were rendered generally invisible by a combination of the dominant ideology and the discursive practices involved in the accomplishment of football commentaries by professional media journalists. In this, I deployed both discourse analysis with its emphasis on how the dominant ideology renders some phenomena visible ("present") and others simultaneously invisible ("absent"). I coupled this with the ethnomethodological tradition of thick, detailed descriptions of observed phenomena in the field.

This was greatly assisted by my earlier conversations with Harold Garfinkel—-the founder of ethnomethodology__ _ while on sabbatical at University of California, Los Angeles (UCLA). He had analyzed my article on "Cathedrals of Sport" in his presentation (Garfinkel, 2007) at the Symposium on "Sociological Research Methods: Beyond the QuantitativeQualitative Divide” held at the Department of Sociology, UCLA in 2007. His general methodological advice was to try and make sense of what is in front of you without abstractions. Nonetheless, I tried to formulate what I wanted to convey using a range of metaphors. These included "unexamined backcloth," "scopic regime," "cultural wallpaper," and "hidden in full sight" (alternatively "hidden in plain view"). Metaphors are central to the interpretation of cultural phenomena in sociology. They deploy figurative rather than literal meanings and promote novel ways of interpreting the social world (see McKinnon, 2012; Simms, 2016). 


\section{The Publication Process}

The published article in Armed Forces \& Society is not the same textually as the first draft of the paper produced at the completion of my research. The manuscript went through a series of iterations which included the pre-submission and the post-submission versions. The initial draft was sent to 12 colleagues for comment. This is a normal part of the creation of a finished draft of an academic paper. Many of their comments were incisive and incorporated into a revised draft. This second version was transformed into a PowerPoint presentation and delivered at the European Association for the Sociology of Sport Conference on "Sport, Unity \& Conflict" in Dublin in 2014. This presentation generated a lively debate in the ensuing discussion and also requests from various participants for a copy of the second draft of the paper. These were sent out and comments from the discussion in Dublin and from colleagues who read the second draft were woven into a revised text.

This third version was submitted to Armed Forces \& Society in December 2014. Extensive comments were received from three referees in February 2015. Two sets of comments were very positive but the third was much more challenging. This necessitated considerable new research, especially on the history of remembrance. This took around 9 months to complete. Once this had been completed, I extensively redrafted and resubmitted the paper in January 2016.

In the reply to the editor, each of the three referees' comments was placed into Microsoft Word and the salient points highlighted in yellow. Beneath each comment, the response was laid out in blue text to assist the editorial team in navigating through the many comments.

Nevertheless, I deemed several comments from the third referee to be inappropriate and rejected 
in a reasoned response to the editor. It is important to incorporate as many comments as possible but sometimes specific comments are misconceived and unhelpful. Subsequently, a second set of comments from the third referee were sent by the editor, and these were dealt with in a similar manner. A further revised manuscript was resubmitted to the journal in March 2016. A couple of weeks later, the editor responded positively to these revisions but suggested further changes to the abstract. Finally, to great relief, the revised manuscript was accepted for publication in May 2016 and published online in December 2016.

Interestingly, throughout the review process, there had been no comments about the use of photographic materials within the paper. The finished published article incorporated the color photographs within the main text of the article (in the manuscript, they had formed a separate appendix) and looked very professional.

\section{The Use of Visual Data}

The published article incorporated nine photographs within the text. This was the first time that Armed Forces \& Society had published an article with photographs which was a pleasing result. My overall argument in the published article was based on a wider series of visual phenomena, including broadcasts of the 2014 and 2015 FA Cup Finals as well as recordings of other football and rugby matches over the same period. Historical contrasts were researched via DVDs of past FA Cup finals (see Liverpool F.A. Cup Finals, 2005; Manchester United F.A. Cup Finals, 2005; 1970s F.A. Cup Finals, 2005; 1980s F.A. Cup Finals, 2005).

Visual data have been marginal to sociology until very recently (see Jay, 1994) despite a longstanding tradition of deploying visual materials in ethnography and sociology. Margaret 
Mead and Gregory Bateson (1942) made extensive use of photography in their seminal study of Balinese society. Likewise, Douglas Harper (1992) also used photographs as the centerpiece for his sociological study of a small workshop. In recent years, there has been a significant increase in the use of visual materials in empirical sociology (see Margolis \& Pauwels, 2011; Pink, 2012; Rose, 2007). This has been particularly the case in the sociology and ethnography of sport (see Hagaman, 1993; Hockey \& Collinson, 2006, 2007; Pink, 2012; Rich \& O’Connell, 2012; Smith, 2008; Wacquant, 2013). Such ocular data can be collected or generated relatively easily nowadays using digital cameras, camcorders, and mobile phones. Five of the images in the article had been provided from my own archive. Three photographs were provided by Bolton Wanderers and one by Carlisle United. Both clubs provided written agreement for their use that was sent to Armed Forces \& Society and subsequently to SAGE which published the article in 2016.

It is also worth pointing out that all the photographs had been taken with the highest resolution in pixels. This is an important element to keep in mind when taking photographs as part of an empirical research project. It is vital to select the highest resolution for photographs as this greatly enhances their visual qualities if they are to be reproduced in any subsequent publication. This applies equally to both print and online publication. I had learned about this personally when four of photographs from my article "Cathedrals of Sport" were used in the World Cup Exhibition in Munich in 2006 (The photographs were displayed at the Exhibition “Ein Spiel___ Viele Welten. One Game___Many Worlds,” Münchner Stadtmuseum, München, May to September 2006. They were also published in Fussball Football: Ein Spiel___Viele Welten/One Game___ Many Worlds, Guggeis [2006].) 


\section{Conclusion and Lessons Learned}

The research I conducted for the article "Association Football, the Military and Invisible Nationalism" was complex and multi-faceted. It involved a wide range of methods including observation, archival research, as well as historical analysis of secondary sources. These were complemented with interviews, focus groups, and the analysis and collection of visual data. I also made use of the comparative method in my examination of football and rugby matches in November 2014. The range of methods applied increased at each successive stage of the research. In any empirical research project, the methods applied emerge during the research process itself. Running in tandem were extensive literature reviews as well as Internet searches. The results of my research were both driven by and interpreted within a set of conceptual and theoretical schemes. Central to the whole research design was the centrality of empirical evidence. This has been described, collected, and analyzed within a broadly Weberian stance. The phenomena examined have been explained rather than either condemned or lauded. They represent an emergent process within contemporary British society. The article brings together the sociology of sport (football) and the sociology of the military and combines both with the deployment of visual data. This triadic combination is unique and innovative within the field. The article also makes use of discourse analysis, ethnomethodology, and the structuralist historical approach of the "Annales" School in a multi-conceptual hermeneutic synthesis. This combining of elements into a syncretic whole was a creative process with no "a priori" rules.

The published article is clearly a long way from the initial starting puzzle and questions posed by the 2014 FA Cup Final. Indeed, the final version published varied significantly from the initial version submitted to the journal. The reviewing process by the journal threw up a 
series of unexpected challenges, all of which had to be successfully navigated. Its publication in the American journal, Armed Forces \& Society is testament to its broader sociological significance.

\section{Exercises and Discussion Questions}

1. How could the research described and analyzed be extended comparatively to encompass other countries? What range of methods could be used?

2. How could the properties of football be explored in relation to other sports? What combination of methods could be used?

3. What are the main obstacles to a "value-neutral" approach to sociology? How would you suggest overcoming these obstacles?

4. What evidence would refute the argument made in the published article? What methods might be combined to achieve this?

5. Explain the value of visual data in supporting empirical research conclusions.

\section{Further Reading}

Penn, R., \& Berridge, D. (2016). The dynamics of quadropoly: League position in English football between 1888 and 2010. International Journal of the History of Sport, 33, 325-340.

Pink, S. (1997). Women and bullfighting: Gender, sex and the consumption of tradition. London, England: Bloomsbury Academic Press.

\section{Web Resources}


Penn, R. (n.d.2015). Cathedrals of sport. Retrieved from

https://mediasite.qub.ac.uk/Mediasite/Play/1e80314991d645ef9c7328e310ca5f671d

International Center of Research Management. Football Management Across Europe. Retrieved from http://www.icrim.eu/football-management/

\section{References}

Arksey, H., \& Knight, P. (1999). Interviewing for social scientists: An introductory resource with examples. London, England: SAGE.

Babbie, E. (2012). The practice of social research (12th ed.). Boston, MA: Wadsworth Publishing.

Braudel, F. (1979). Civilisation materielle, économie et capitalisme, 15e-18e siècle [Civilisation and capitalism. 15th-18th centuries]. Paris, France: Colin Press.

Formatted: French (France)

Bryman, A. (2012). Social research methods (4th ed.). Oxford, UK: Oxford University Press.

Burke, P. (Ed.). (1972). Economy and society in early modern Europe: Essays from “Annales.” London, England: Routledge \& Kegan Paul.

Duby, G. (1973). Le Dimanche de Bouvines. Paris, France: Gallimard.

Commented [CE3]: AQ3

Emmison, M., Smith, P., \& Mayall, M. (2012). Researching the visual (2nd ed.). London, England: SAGE.

Garfinkel, H. (1967). Studies in ethnomethodology. Englewood Cliffs, NJ: Prentice Hall. 
Garfinkel, H. (2002). Ethnomethodology’s program: Working out Durkheim’s aphorism.

Lanham, MD: Rowman \& Littlefield.

Garfinkel, H. (2007). Venerated things of Football stadia architectural shrines in irreconcilably alternate details of "representations" versus "descriptive descriptions." Paper presented to the Symposium on "Sociological Research Methods: Beyond the Quantitative-Qualitative Divide,” Department of Sociology, University of California, Los Angeles.

Commented [CE4]: AQ4

Gee, J. (1999). An introduction to discourse analysis: Theory and method. London, England: Routledge.

Gray, D. (2013). Doing research in the real world (3rd ed.). London, England: SAGE.

Guggeis, K. (2006). Fussball Football: Ein Spiel_Viele Welten/One Game-Many Worlds München. Stuttgart, Germany: Arnoldsche.

Commented [CE5]: AQ5

Hagaman, D. (1993). The joy of victory, the agony of defeat: Stereotypes in newspaper feature photographs. Visual Studies, 8, 48-66.

Hall, J., \& Bryant, J. (2005). Historical methods in the social sciences: Four volume set. London, England: SAGE.

Harper, D. (1992). Working knowledge: Skill and community in a small shop Chicago. Chicago, IL: Chicago University Press.

Haw, K., \& Hadfield, M. (2011). Video in social science research. London, England: Routledge.

Heritage, J. (1984). Garfinkel and ethnomethodology. Cambridge, UK: Polity Press. 
Hobsbawn, E., \& Ranger, T. (Eds.). (1983). The invention of tradition. Cambridge, UK: Cambridge University Press.

Hockey, J., \& Collinson, A. (2006). Seeing the way: Visual sociology and the distance runner's perspective. Visual Studies, 21, 70-81.

Hockey, J., \& Collinson, A. (2007). Grasping the phenomenology of sporting bodies. International Review for the Sociology of Sport, 42, 115-131.

Jay, M. (1994). Downcast eyes: The denigration of vision in twentieth-century French thought. Berkeley: University of California Press.

Johnstone, B. (2008). Discourse analysis (2nd ed.). Oxford, UK: Blackwell.

Kreuger, R., \& Casey, M. (2014). Focus groups: A practical guide for applied research (5th ed.). London, England: SAGE.

Lapenta, F. (2011). Some theoretical and methodological views on photo-elicitation. In E.

Margolis \& L. Pauwels (Eds.), The SAGE handbook of visual research methods. London, England: SAGE.

Le Roy Ladurie, E. (1978). Montaillou: Cathars and Catholics in a French village, 1294-1324.

Harmondsworth, UK: Penguin Books.

Liverpool FC F.A. Cup Finals: Boxed Set. (2005). ASIN: B011073164.

Manchester United F.A. Cup Finals: Boxed Set. (2005). ASIN: B00061RZEW. 
Margolis E., \& Pauwels L. (Eds.). (2011). The SAGE handbook of visual research methods.

London, England: SAGE.

McKinnon, A. (2012). Metaphors in and for the sociology of religion: Towards a theory after

Nietzsche. Journal of Contemporary Religion, 27, 203-216.

Mead, M., \& Bateson, G. (1942). Balinese character: A photographic analysis New York. New York, NY: Academy of Sciences.

Morgan, D., \& Kreuger, R. (1997). The focus group kit: Volumes 1-6. London, England: SAGE.

1970s F.A. Cup Finals: Boxed Set. (2005). ASIN: B00061RZEZ.

1980s F.A. Cup Finals: Boxed Set. (2005). ASIN: B00061RZEM.

Penn, R. (1985). Skilled workers in the class structure. Cambridge, UK: Cambridge University Press.

Penn, R. (2005). Cathedrals of sport: Football stadia in contemporary England. Soccer Review, 4,

27-30. Retrieved from http://www.supporters-direct.org/englandwales/library.htm

Penn, R. (2006a). Le Cattedrali dello sport: Gli stadi di calcio nell' Inghilterra contemporanea

[Cathedrals of sport: Cotemporary English football stadia]. In N. Bortoletto \& B. Mazza

(Eds.), Tempi e spazi dello sport: Italia-Inghilterra modelli a confronto [Time and Space:

Italian and English Models Compared]. Teramo, Italy: Il Piccolo Libro.

Penn, R. (2006b). Social change and economic life in Britain. Bologna, Italy: Homeless Books. 
Penn, R. (2013). Football, nationalism and globalization: A comparison of English and Italian football between 1930 and 2010. European Journal for Sport and Society, 10, 345-364.

Penn, R. (2014). The sociological analysis of historical census data using graphical representations: An illustration from the 1921 census of England and Wales. London, England: SAGE.

Penn, R. (2015). “Cathedrals of sport” video publication. Retrieved from http://www.icrim.eu/football-management/ or at https://mediasite.qub.ac.uk/Mediasite/Play/1e80314991d645ef9c7328e310ca5f671d

Penn, R. (2016). Football talk: Sociological reflections on the dialectics of language and football. European Journal for Sport \& Society, 13, 154-166.

Penn, R., \& Berridge, D. (2016). Football and the military in contemporary Britain: An exploration of invisible nationalism. Armed Forces \& Society. Advance online publication. doi:10.1177/0095327X16682784

Pink, S. (Ed.). (2012). Advances in visual methodology. London, England: SAGE.

Rich, E., \& O’Connell, K. (2012). Visual methods in physical culture: Body culture exhibition. In K. Young \& M. Atkinson (Eds.), Qualitative research on sport and physical culture. Bingley, UK: Emerald Group.

Rose, G. (2007). Visual methodologies: An introduction to the interpretation of visual materials (2nd ed.). London, England: SAGE. 
Schutz, A. (1962). Collected papers I: The problem of social reality. The Hague, The Netherlands: Marinus Nijhoff.

Simms, K. (2016). Metaphor and symbol. In N. Keane \& C. Lawn (Eds.), A companion to hermeneutics. Chichester, UK: John Wiley \& Sons.

Commented [CE9]: AQ9

Smart, B., Peggs, K., \& Burridge, J. (2013). Observation methods: Four volume set. London, England: SAGE.

Smith, R. (2008). Pain in the act: The meaning of pain amongst Professional Wrestlers.

Qualitative Sociology, 31, 129-148.

The F.A. Cup Finals. (2011). British Pathé. ASIN: B004CXLGOA.

Tottenham Hotspur The F.A. Cup Classic Collection Boxed Set. (2005). ASIN: B000BGEZC2.

Van Leeuwen, T. \& Jewitt, C. (2001). Handbook of visual analysis. London, England: SAGE.

Wacquant, L. (2004). Body and soul: Notebooks of an apprentice boxer. Oxford, UK: Oxford University Press.

Wacquant, L. (2013). Habitus as topic and tool: Reflections on becoming a Prizefighter. In R.

Garcia \& D. Spencer (Eds.), Fighting scholars: Habitus and ethnographies of martial arts and combat sports. London: Anthem Press.

Weber, M. (1949). Max Weber on the methodology of the social sciences (E. Shils \& H. Finch, Trans.). Glencoe, IL: Free Press. 
Whyte, W. F. (1943). Street corner society: The social structure of an Italian slum. Chicago, IL: Chicago University Press. 